\title{
PENINGKATAN KEMAMPUAN GURU DALAM PEMANFAATAN MICROSOFT OFFICE POWERPOINT UNTUK MENINGKATKAN PEMBELAJARAN DI SMP SWASTA 6 MUHAMMADIYAH LHOKSEUMAWE DAN SMP NEGERI 4 LHOKSEUMAWE
}

\author{
SRI ARYATI \\ SMP Negeri 4 Lhokseumawe dan \\ SMPS Muhammadiyah 6 Lhokseumawe \\ e-mail: sriaryati170@yahoo.com
}

\begin{abstract}
ABSTRAK
Program PowerPoint merupakan program yang digunakan untuk membuat slide atau presentasi yang dikeluarkan olah Microsoft sebagai produsennya. Penggunaan yang paling penting dalam mengoperasikan PowerPoint adalah mengolah slide. Pembuatan slide yang polos tanpa diberi efek akan kurang menarik, oleh karena itu anda perlu merubahnya menjadi tampilan yang menarik. Berdasarkan hasil evaluasi di sekolah SMP Swasta Muhammadiyah 6 Lhokseumawe dan SMP Negeri 4 Lhokseumawe pada tahun 2019 tentang delapan standar nasional pendidikan (SNP), masih terdapat kelemahan-kelemahan pada kompetensi standar proses. Dengan adanya pelatihan terkait pemanfaatan microsoft powerpoint didapatkan kenaikan signifikan dengan rata-rata presentase sebesar 43,25\%
\end{abstract}

Kata kunci : Microsoft PowerPoint, Media Pembelajaran, Peningkatan Guru

\section{PENDAHULUAN}

Undang-Undang Nomor 20 Tahun 2003 tentang Sistem Pendidikan Nasional, Pasal 1 angka 1 menyatakan bahwa pendidikan adalah usaha sadar dan terencana untuk mewujudkan suasana belajar dan proses pembelajaran agar peserta didik secara aktif mengembangkan potensi dirinya untuk memiliki kekuatan spiritual keagamaan, pengendalian diri, kepribadian, kecerdasan, akhlak mulia, serta keterampilan yang diperlukan dirinya, masyarakat, bangsa dan negara.

Standar Proses adalah kriteria mengenai pelaksanaan pembelajaran pada satuan pendidikan untuk mencapai Standar Kompetensi Lulusan. Standar Proses dikembangkan mengacu pada Standar Kompetensi Lulusan dan Standar Isi yang telah ditetapkan sesuai dengan ketentuan dalam Peraturan Pemerintah Nomor 19

Tahun 2005 tentang Standar Nasional Pendidikan sebagaimana telah diubah dengan Peraturan Pemerintah Nomor 32 Tahun 2013 tentang Perubahan atas Peraturan Pemerintah Nomor 19 Tahun 2005 tentang Standar Nasional Pendidikan. Proses Pembelajaran pada satuan pendidikan diselenggarakan secara interaktif, inspiratif, menyenangkan, menantang, memotivasi peserta didik untuk berpartisipasi aktif, serta memberikan ruang yang cukup bagi prakarsa, kreativitas, dan kemandirian sesuai dengan bakat, minat, dan perkembangan fisik sertavpsikologis peserta didik. Untuk itu setiap satuan pendidikan melakukan perencanaan pembelajaran, pelaksanaan proses pembelajaran serta penilaian proses pembelajaran untuk meningkatkan efisiensi dan efektivitas ketercapaian kompetensi lulusan.

Sejak diberlakukan Kurikulum 2013 banyak sekolah khususnya di Lhokseumawe berusaha memperbaiki kualitas pembelajaran yang dilaksanakan melalui berbagai cara, salah satunya dengan pengadaan workshop sehingga nantinya guru mampu menerapkan pembelajaran yang menarik sehingga meningkatnya mutu pendidikan di sekolah. Peningkatan mutu pendidikan merupakan salah satu pilar pokok pembangunan pendidikan di Indonesia. Pendidikan yang bermutu akan menghasilkan sumber daya manusia yang cerdas, kreatif dan kompetitif sesuai dengan visi Kementerian Pendidikan Nasional. Untuk mewujudkan visi tersebut diperlukan upaya peningkatan mutu pendidikan secara berkelanjutan oleh semua pihak. Perkembangan di bidang pendidikan yang 


\section{EDUTECH : Jurnal Inovasi Pendidikan Berbantuan Teknologi Vol. 1 No. 2 Agustus 2021, e-ISSN : 2797-0140 | p-ISSN : 2797-0590}

semakin pesat, menuntut kesiapan dari satuan pendidikan untuk melakukan perubahan sesuai tuntutan dan kebijakan yang ditetapkan oleh pemerintah. Hal ini menyebabkan setiap satuan pendidikan harus memiliki Rencana Kerja yang jelas dan terperinci untuk melaksanakan semua kegiatan sekolah agar lebih terarah.

Setiap kegiatan pada satuan pendidikan dikelola atas dasar Rencana Kerja Sekolah (RKS) yang merupakan penjabaran rinci dari Rencana Kerja Jangka Menengah (RKJM) satuan pendidikan yang meliputi masa empat tahun sesuai dengan Peraturan Pemerintah Nomor 19 tahun 2005 tentang Standar Nasional Pendidikan, Pasal 53 ayat (1). Oleh karenanya setiap satuan pendidikan wajib menyusun Rencana Kerja Jangka Menengah (RKJM) yang selanjutnya disebut Rencana Kerja Sekolah (RKS) yang akan menggambarkan tujuan yang akan dicapai dalam kurun waktu empat tahun dan Rencana Kegiatan dan Anggaran Sekolah (RKAS) yang dinyatakan dalam Rencana Kegiatan dan Anggaran Sekolah (RKAS) dilaksanakan berdasarkan Rencana Kerja Sekolah.

Perubahan yang mengarah peningkatan mutu harus dilaksanakan secara signifikan, akuntabel dan transparan agar dapat mengimbangi pesatnya kemajuan informasi sehingga peranan sekolah sebagai mediator, transpormator, dan informator di satuan pendidikan yang langsung berhadapan dengan masyarakat dapat berjalan sesuai dengan tujuan pendidikan sebagaimana tertuang dalam Standat Nasional Pendidikan dan juga sesuai dengan sasaran pendidikan seperti dijelaskan dalam Sistem Pendidikan Nasional.

Untuk itu, sekolah harus membuat rencana strategi yang kompleksitas dan fleksibelitas yang sesuai dengan kebutuhan lingkungan yang dapat mengakomodir semua keinginan dan harapan masyarakat lingkungan selaku mitra pendidikan untuk bersama membangun, memelihara dan mengawasi sehingga peranan stockholder dalam Managemen Berbasis Sekolah dapat terlaksana dengan baik.

Rencana Strategi Sekolah itu kemudian dikemas lebih pendek periodenya menjadi rencana kerja empat tahunan dan akhirnya sekolah dengan pertimbangan komite perlu membuat Rencana Kerja Tahunan Sekolah (RKTS) yang digunakan sebagai acuan dalam pelaksanaan kegiatan di sekolah.

Selain itu, hal yang perlu diperhatikan untuk meningkatkan mutu pendidikan di sekolah adalah kinerja guru dan kepala sekolah. Untuk meningkatkan mutu guru maka guru di tuntuk bisa mengoperasikan komputer. Perkembangan Teknologi Informasi dan Komunikasi (TIK) yang begitu pesat digunakan dalam berbagai disiplin ilmu serta membantu berbagai pekerjaan, termasuk juga digunakan dalam dunia pendidikan. Pada abad 21 ini keberadaan TIK sangat penting untuk membantu dan memudahkan dalam pelaksanaan pembelajaran. Tuntutan kompetensi guru dan kepala sekolah dalam memanfaatkan TIK untuk meningkatkan kualitas pembelajaran merupakan suatu hal yang tidak dapat diabaikan. Namun, pelaksanaan dilapangan masih banyak guru yang belum mampu mengoperasikan komputer.

Salah satu upaya untuk meningkatkan mutu pendidikan di sekolah adalah guru dituntut agar bisa mengaplikasikan komputer, seperti guru mampu menyediakan media berupa slide PowerPoint supaya proses belajar mengajar menjadi menyenangkan. Microsoft PowerPoint adalah salah satu perangkat lunak yang dapatt digunakan untuk merancang dan menayangkan slide presentasi. Microsoft PowerPoint memungkinkan integrasi file-file multimedia (gambar, suara, video) ke dalam tayangan presentasi. Selain itu, slide presentasi yang dibuat dapat dicetak dalam bentuk handout, slide transparan (untuk digunakan dengan overhead projector), maupun disimpan sebagai file HTML (hypertext markup languange) agar dapat ditanyangkan dalam situs web.

Program PowerPoint merupakan program yang digunakan untuk membuat slide atau presentasi yang dikeluarkan olah Microsoft sebagai produsennya. Penggunaan yang paling penting dalam mengoperasikan PowerPoint adalah mengolah slide. Pembuatan slide yang polos tanpa 
diberi efek akan kurang menarik, oleh karena itu anda perlu merubahnya menjadi tampilan yang menarik.

Berdasarkan hasil evaluasi di sekolah SMP Swasta Muhammadiyah 6 Lhokseumawe dan SMP Negeri 4 Lhokseumawe pada tahun 2019 tentang delapan standar nasional pendidikan (SNP), masih terdapat kelemahan-kelemahan pada kompetensi standar proses. Hasil rekomendasi pada kompetensi standar proses sekolah perlu memfasilitasi guru untuk menerapkan pembelajaran yang menyenangkan untuk mendorong semangat belajar, motivasi, minat, kreativitas, inisiatif, inspirasi, inovasi dan kemandirian.

\section{METODE PENELITIAN}

Jenis penelitian ini yaitu Penelitian Tindakan Kelas (PTK) atau Classroom Action Research (CAR). Suharsimi Arikunto, dkk. (2009: 3) mengartikan bahwa penelitian tindakan kelas merupakan suatu pencermatan terhadap kegiatan belajar berupa sebuah tindakan, yang sengaja dimunculkan dan terjadi dalam sebuah kelas secara bersama. Suharsimi Arikunto, dkk. (2009: 16) menjelaskan bahwa dalam penelitian ini terdiri dari empat tahapan yang dilalui, yaitu (1) perencanaan, (2) pelaksanaan, (3) pengamatan dan (4) refleksi. Keempat tahap dalam penelitian tindakan tersebut adalah unsur untuk membentuk sebuah siklus, yaitu satu putaran kegiatan beruntun, yang kembali ke langkah semula. Penelitian ini dilaksanakan dalam dua siklus. Siklus I dilaksanakan selama dua pertemuan, siklus II dilaksanakan selama dua pertemuan. Setiap pertemuan terdiri dari dua jam pelajaran.

\section{HASIL DAN PEMBAHASAN}

\section{Hasil}

Tabel 1. Rekap Penilaian Terhadap Penyenggaraan Program Peningkatan Kemampuan Guru Dalam Pemanfaatan Microsoft Office Powerpoint

\begin{tabular}{|c|c|c|c|c|c|c|c|}
\hline \multirow{2}{*}{ No } & \multirow{2}{*}{ Uraian } & \multicolumn{4}{|c|}{ Nilai } & \multirow[t]{2}{*}{ Jumlah } & \multirow[t]{2}{*}{ Jumlah } \\
\hline & & 4 & 3 & 2 & $\mathbf{1}$ & & \\
\hline 1. & Kelengkapan sarana dan prasarana & & 12 & & & 4 & 12 \\
\hline 2. & Kesiapan panitia workshop & 16 & & & & 4 & 16 \\
\hline 3. & Kesesuaian pelaksanaan dengan & 16 & & & & 4 & 16 \\
\hline 4. & Penyampaian materi oleh narasumber & 16 & & & & 4 & 16 \\
\hline 5. & Kesesuaian materi yang disampaikan & 16 & & & & 4 & 16 \\
\hline 6. & $\begin{array}{l}\text { Kenyamanan situasi dan kondisi } \\
\text { selama kegiatan workshop }\end{array}$ & 12 & 3 & & & 4 & 15 \\
\hline 7. & $\begin{array}{l}\text { Pemberian motivasi kepada peserta } \\
\text { workshop }\end{array}$ & 16 & & & & 4 & 16 \\
\hline 8. & Penguasaan materi & 12 & 3 & & & 4 & 15 \\
\hline 9. & $\begin{array}{l}\text { Fasilitator mambantu peerta } \\
\text { mencapai tujuan }\end{array}$ & 4 & 9 & & & 4 & 13 \\
\hline
\end{tabular}




\begin{tabular}{|c|l|c|c|c|c|c|c|}
\hline 10. & $\begin{array}{l}\text { Tanggapan peserta terhadap } \\
\text { kegiatan workshop }\end{array}$ & 9 & 4 & & & 4 & 13 \\
\hline 11. & Metode yang digunakan narasumber & 4 & 9 & & & 4 & 13 \\
\hline 12. & Ketetapan yang digunakan & 12 & & & & 4 & 12 \\
\hline \multicolumn{6}{|c|}{ Jumlah } & & $\mathbf{1 7 3}$ \\
\hline
\end{tabular}

Dari data hasil penilaian terhadap penyenggaraan program peningkatan kemampuan guru dalam pemanfaatan microsoft office powerpoint didapatkan rata-rata peningkatan kemampuan guru yang sangat signifikan dimana peningkatan tersebut sebesar 43,25\% dari jumlah skor yang di dapatkan yaitu 173 .

\section{Pembahasan}

Peningkatan kompetensi yang dicapai melalui pendidikan dan pelatihan akan berpengaruh nyata terhadap proses pembelajaran di kelas yang pada akhirnya akan memberikan dampak yang positif terhadap mutu sekolah dan mutu peserta didik. Salah satu upaya untuk meningkatkan mutu pendidikan di sekolah adalah guru dituntut agar bisa mengaplikasikan komputer, seperti guru mampu menyediakan media berupa slide PowerPoint supaya proses belajar mengajar menjadi menyenangkan. Oleh karena itu guru di tuntut bisa menggunakan PoworPoint pada saat proses pembelajaran.

Adapun program pembimbingan kepala sekolah dalam penyusunan Rencana Kerja Tahunan Sekolah disusun sebagai acuan bagi sekolah untuk melaksanakan program sekolah dalam kurun waktu satu tahun dan dapat mengevaluasi pelaksanakaan untuk tahun berikutnya yang dapat dijadikan dasar dalam penyusunan RKAS sekolah,guru dan kepala sekolah dapat melaksanakan pengembangan keprofesionalannya agar meningkat, Semoga program bimbingan ini dapat memberikan konstribusi dalam upaya meningkatkan penyusunan Rencana Kerja Tahunan Sekolah (RKTS) pada Kepala Sekolah di SMP Swasta Muhammadiyah 6

Lhokseumawe dan SMP Negeri 4 Lhokseumawe.

\section{KESIMPULAN}

Bimbingan dan pelatihan (Bimlat) guru dan kepala sekolah sangat bermanfaat untuk meningkatkan kompetensi guru dan kepala sekolah, untuk itu alangkah lebih baik kegiatan bimbingan dan pelatihan (Bimlat) guru dan kepala Sekolah dilakukan dengan baik dan terus menerus supaya mendapatkan hasil yang baik. Pendidikan dan pelatihan merupakan salah satu bentuk kegiatan dari program pengembangan sumber daya manusia yakni guru dan kepala sekolah. Pengembangan guru dan kepala sekolah merupakan proses perbaikan mutu dan kompetensi melalui berbagai macam pendekatan yang menekankan realisasi diri, kesadaran, pertumbuhan pribadi dan pengembangan diri.

\section{DAFTAR PUSTAKA}

Acep Yonni, dkk. (2010). Menyusun Penelitian Tindakan Kelas. Yogyakarta: Familia. Achmad Sugandi, dkk. (2007). Teori Pembelajaran. Semarang: UPT MKK UNNES.

Bahari, Nooryan. (2008). Kritik Seni Wacana, Apresiasi dan Kreasi. Yogyakarta: Pustaka Pelajar. BSNP. (2006). Standar Isi Untuk Satuan Pendidikan Dasar dan Menengah. Jakarta: Depdiknas. BSNP. (2007). Pedoman Penilaian Hasil Belajar Di Sekolah Dasar. Jakarta: Depdiknas. Catharina Tri Anni, dkk. (2007). Psikologi Belajar. Semarang: UPT MKK UNNES. 


\section{EDUTECH : Jurnal Inovasi Pendidikan Berbantuan Teknologi

Dimyati dan Mudjiono. (1999). Belajar dan Pembelajaran. Jakarta: Rineka Cipta.

Hamalik, Oemar. (2007). Kurikulum dan Pembelajaran. Jakarta: PT Bumi Aksara.

Peraturan Pemerintah Republik Indonesia Nomor 19 Tahun 2005 Tentang Standar Nasional Pendidikan.

Sadiman, Arief S. (2009). Media Pendidikan. Jakarta: Rajawali Pers. Sahman, Humar. 2003. Mengenali Dunia Seni Rupa. Semarang. IKIP Semarang Press.

Saminanto. (2010). Ayo Praktik PTK: Penelitian Tindakan Kelas. Semarang: RaSAIL Media Group.

Sudjana, Nana. (2010). Dasar-Dasar Proses Belajar Mengajar. Bandung: Sinar Baru Algesindo. Sugiono. (2008). Metode Penelitian Pendidikan. Bandung: Alfabeta.

Sugono, Dendy. (2008). Kamus Bahasa Indonesia. Jakarta: Pusat Bahasa Depdiknas.

Suharsimi Arikunto, dkk. (2009). Penelitian Tindakan Kelas. Jakarta: PT Bumi Aksara.

Thobroni, Muhammad dan Arif Mustofa. (2011). Belajar \& Pembelajaran. Jogjakarta: Ar-Ruzz Media. 